\title{
Modelling the nitrogen deposition to afforested systems
}

\author{
A. Bleeker ${ }^{1^{*}}$ \\ W.P.A. van Deursen ${ }^{2}$ \\ 1 TNO, Environment and Geosciences, P.O. Box 342, 7300 AH Apeldoorn, the Netherlands, \\ * Present address: Energy Centre of the Netherlands (ECN), P.O. Box, 1755 ZG Petten, the Netherlands \\ ${ }_{2}$ Carthago Consultancy, Oostzeedijk Beneden 23a, 3062VK Rotterdam, the Netherlands
}

Published in Environmental effects of Afforestation in north-western Europe - From field experiments to decision support - edited by Gerrit W. Heil, Bart Muys and Karin Hansen, (2006), 109-128, Springer, The Netherlands 


\title{
CHAPTER 5
}

\section{MODELLING THE NITROGEN DEPOSITION TO AFFORESTED SYSTEMS}

\author{
A. BLEEKER ${ }^{1 *}$ and W.P.A. VAN DEURSEN ${ }^{2}$ \\ ${ }^{1}$ TNO, Environement and Geosciences, P.O. Box 342, 7300,Laan van Westerenk \\ 501, AH Apeldoorn, the Netherlands, * Present address: Energy Centre of the \\ Netherlands (ECN), P.O. Box, 1755 ZG Petten, the Netherlands, E-mail: \\ a.bleeker@ecn.nl, ${ }^{2}$ Carthago Consultancy, Oostzeedijk Beneden 23a, 3062VK \\ Rotterdam, the Netherlands
}

\begin{abstract}
Eutrophication largely results from deposition of atmospheric N. The emission of $\mathrm{N}$ mainly originates from agriculture $\left(\mathrm{NH}_{3}\right)$, traffic, power plants and industry $\left(\mathrm{NO}_{\mathrm{x}}\right)$. The most important ammonia source is emission from animal manure. The extent of this emission depends on manure composition and meteorological conditions. After $\mathrm{N}$ is emitted (either as $\mathrm{NH}_{3}$ or as $\mathrm{NO}_{\mathrm{x}}$ ) it will be transported over short or long distances. Deposition rates vary with the structure of the earth surface, and it is often assumed that the interceptive properties of vegetation, expressed as roughness length, are constant and the same for all wind speeds and all transferable quantities. Careful evaluation of individual components of the overall transfer resistance is crucial to an understanding of how and where $\mathrm{N}$ will be distributed within a particular forest canopy. In the context of local scale ammonia, like encountered in the AFFOREST project, $\mathrm{NH}_{\mathrm{x}}$ will be mostly dry deposited to the forest. The Eutrend model was used for the calculation of $\mathrm{N}$ deposition, and it calculates concentrations and depositions as a function of surface characteristics. The model is able to describe both short and long-distance transport. The land use changes occurring in an afforestation process have different effects. The first effect is related to the removal of especially $\mathrm{NH}_{3}$ emission, while the second is related to changing deposition characteristics when turning agricultural land into forest. On top of that, after afforestation the deposition of $\mathrm{N}$ will change due to the effect of growing forest. Growing forest will have an effect on the roughness length, which is an important factor determining the deposition velocity. Emission from a specific location is not only deposited at that same location but is also transported and deposited in surrounding areas. Because of such transport through the air, a spatial interaction between the emission source and the deposition receptor is introduced as a complicating factor. Further investigation was needed to evaluate the relevancy of spatial interaction for the AFFORESTsDDS. After corrections, the AFFOREST-sDSS is realistically well able to describe the deposition situation after a certain amount of years after afforestation.
\end{abstract}

109

G.W.Heil et al (eds.) Environ. effects of Afforestation in north-western Europe, 109 - 128. (c) 2006 Springer. Printed in the Netherlands. 


\section{INTRODUCTION}

One of the most environmentally damaging air pollutants in north-western Europe is nitrogen $(\mathrm{N})$. It is deposited at rates that vary with the structure of the earth surface. Eutrophication of ecosystems largely results from deposition of atmospheric $\mathrm{N}$ originating from liquid manure produced and applied in big quantities in the intensive farming systems in this part of Europe (e.g. Millennium Ecosystem Assessment 2005). It is often assumed that the interceptive properties of vegetation, expressed as roughness length, are constant and the same for all wind speeds and all transferable quantities. Careful evaluation of individual components of the overall transfer resistance is crucial to an understanding of how and where $\mathrm{N}$ will be distributed within a particular forest canopy.

Nitrogen deposition is an important input to afforested systems in north-western Europe, being of influence on both nitrate leaching and carbon sequestration in a direct or indirect way. In this chapter, the deposition of $\mathrm{N}$ is discussed with focus on the specific way in which $\mathrm{N}$ deposition is modelled within the AFFOREST-sDSS.

The next section will give a general description of the aspects involved in the source-receptor pathway with respect to $\mathrm{N}$ deposition. Hereafter, the general change in emission and deposition after afforestation is described. Lastly, an overview of some specific items that needed special attention when implementing $\mathrm{N}$ deposition in the AFFOREST-sDSS is given and further implementation issues are discussed.

\section{NITROGEN DEPOSITION: FROM SOURCE TO RECEPTOR}

In the context of afforestation in north-westen Europe, $\mathrm{N}$ deposited to the new forests is a combination of $\mathrm{NH}_{\mathrm{x}}$ and $\mathrm{NO}_{\mathrm{y}}$ components. Reduced $\mathrm{N}\left(\mathrm{NH}_{\mathrm{x}}\right)$ consists of ammonia $\left(\mathrm{NH}_{3}\right)$ and its reaction product ammonium $\left(\mathrm{NH}_{4}{ }^{+}\right)$, while oxidised $\mathrm{N}\left(\mathrm{NO}_{y}\right)$ consists of $\mathrm{NO}_{\mathrm{x}}\left(\mathrm{NO}_{2}+\mathrm{NO}\right)$ and its reaction product nitrate $\left(\mathrm{NO}_{3}{ }^{-}\right)$. The following description of the source-receptor pathway is divided in two main parts: the emission of $\mathrm{N}$ and the transport and deposition of $\mathrm{N}$.

\subsection{Emission of nitrogen}

The emission of $\mathrm{N}$ mainly originates from agriculture $\left(\mathrm{NH}_{3}\right)$, traffic, power plants and industry $\left(\mathrm{NO}_{\mathrm{x}}\right)$. The most important ammonia source is emission from animal husbandry and manure. The extent of this emission depends on the composition of manure and meteorological conditions. The most important sources are emission during grazing, emission from stables, emission from manure storage and emission during manure spreading.

An important factor determining the overall ammonia emission is the total manure excretion, which is also a starting point for the calculation of ammonia emission. The $\mathrm{N}$ excretion is calculated as the difference between the $\mathrm{N}$ amount consumed (in the fodder) and the $\mathrm{N}$ immobilisation in animal products (e.g. milk, meat) for each animal species for an average situation during specific years.

While the ammonia emissions mainly originate from low level sources (small height), $\mathrm{NO}_{\mathrm{x}}$ is emitted from sources at different heights. The $\mathrm{NO}_{\mathrm{x}}$ emissions from 
traffic are emitted at a relatively small height (1-3 meters), while $\mathrm{NO}_{\mathrm{x}}$ emissions from power plants and industrial sites are emitted at heights varying from 15-200 meters. This emission height causes the emissions to be transported over different distances and spread over areas differing in size. The small height sources will mainly contribute to areas at close range from the emission point, while the high sources also will contribute to larger distances from the source.

The $\mathrm{NO}_{\mathrm{x}}$ emissions are mainly caused by processes in which fossil fuels are burnt. However, $\mathrm{NO}_{\mathrm{x}}$ emissions can also be emitted from soils through denitrification and formed through conversion of $\mathrm{NH}_{3}$ by $\mathrm{OH}$ in the atmosphere. Natural emissions of $\mathrm{N}$ comprise lightning and stratospheric destruction of $\mathrm{N}_{2} \mathrm{O}$.

\subsection{Transport and deposition of nitrogen}

After $\mathrm{N}$ is emitted it will be transported over short or long distances. The total deposition of $\mathrm{N}$ mainly consists of wet and dry deposition. A third form is the cloud or fog deposition, also called occult deposition. Cloud and fog water deposition is the process where cloud and fog water droplets are directly intercepted by the earth's surface. Because quantitative information on the contribution of this type of deposition in the different parts of Europe is scarce, the cloud or fog deposition is normally not taken into account in the description of the total deposition. However, especially for medium and high altitude areas, the contribution of cloud deposition to the total deposition can be in the range of 20-50\% (Fowler et al. 1991; Bleeker et al. 2000). However, the study areas of AFFOREST are all situated in low altitude areas and occult deposition can be neglected.

\subsubsection{Wet deposition}

Wet deposition is the process by which atmospheric pollutants are delivered to the earth's surface by rain, hail or snow. It is defined as the natural process by which atmospheric pollutants are attached to and dissolved in cloud and precipitation droplets (or particles) and delivered to the earth's surface. The amount of compounds thus received per unit of surface area is defined as wet deposition. There are two main processes involved in wet deposition:

- In-cloud scavenging also called rain-out

- Below-cloud scavenging also called wash-out

In-cloud scavenging is the process in which cloud droplets are formed due to condensation of rather humid air (Hov et al. 1987). When the air contains particles (aerosols, dust), droplets will form more rapidly, because particles act as condensation nuclei.

Below-cloud scavenging is the process where uptake of gases and/or particles can occur during the downward transport of the droplet to the earth's surface. It is a very efficient removal mechanism for soluble gases (like $\mathrm{NH}_{3}$ ) and aerosols with a diameter larger than $1 \mu \mathrm{m}$ (Hicks et al. 1989). 


\subsubsection{Dry deposition}

Dry deposition is the process where gases and particles are deposited directly from the atmosphere to vegetation, here forest. The process is governed by 1) the concentration in air, 2) turbulent transport processes in the boundary layer, 3) the chemical and physical nature of the depositing species and 4) the efficiency of the surface to capture or absorb gases and particles. The flux of a trace gas is given as:

$$
F=V_{d}(z) c(z)
$$

where:

$c(z)$ is the concentration at height $z$;

$V_{d}(z)$ is the dry deposition velocity at height $z$ (Chamberlain 1966)

The parameterisation of the dry deposition velocity can be based on a description with a resistance analogy or Big Leaf Model (e.g. Thom 1975; Hicks et al. 1987; Fowler 1978; Erisman et al. 1994). In this resistance model, the most important deposition pathways by which the component is transported to and subsequently taken up at the surface are parameterised. The surface resistance is affected by meteorology, leaf area, stomatal physiology, soil and external leaf surface $\mathrm{pH}$, and presence and chemistry of water drops and films. Especially, the state of the leaf and soil surface (i.e. the presence of water films and snow) is an important variable governing the deposition of soluble gases like $\mathrm{NH}_{3}$. More information on the use of different resistances for calculating the deposition velocity can be found in Erisman et al. (1994).

In the context of local scale ammonia emission, like encountered in the AFFOREST region, dry deposition is the most important way in which $\mathrm{NH}_{\mathrm{x}}$ will be deposited to the surface. It is known that $\mathrm{NH}_{\mathrm{x}}$ is both a local and a long-distant pollutant. However, because of the very local character of the items discussed in this study, $\mathrm{NH}_{\mathrm{x}}$ is mainly removed from the atmosphere in the form of dry deposition of $\mathrm{NH}_{3}$ close to the source. At some distance from the source, it is removed in the form of wet deposition of $\mathrm{NH}_{4}^{+}$, partly because $\mathrm{NH}_{4}{ }^{+}$is a reaction product that is first formed only after some time (Asman \& Van Jaarsveld 1990). Therefore, wet deposition of $\mathrm{NH}_{\mathrm{x}}$ between the source and direct surroundings does not contribute much to the total deposition (dry + wet) of ammonia.

\subsubsection{The Eutrend model}

Due to the fact that it is almost impossible to compile spatial distributions of the deposition of $\mathrm{N}$ based on measurements only, models must be used for calculating the deposition (both wet and dry) on different scales. The Eutrend model used for the AFFOREST calculations ( $\mathrm{v}$ 1.17) is a version of the Operational Priority Substances (OPS) model. OPS was developed by the National Institute of Public Health and Environment in the Netherlands (RIVM) for calculating transport and average concentrations and depositions of acidifying compounds (such as ammonia and $\mathrm{N}$ oxides) on a local to national scale (Asman \& Van Jaarsveld 1992; Van Jaarsveld 
1995). Emission, dispersion, advection, chemical conversion and wet and dry deposition were included in the model. Dry deposition is modelled using a resistance approach, in which the dry deposition velocity is constructed from resistances of both the atmosphere and the receiving surface. A general description of the modelled processes is given in Van Jaarsveld (1995).

Eutrend v1.17) calculates concentrations and depositions as a function of surface characteristics. The model is able to describe both short and long-distance transport. The advection of this model is based on meteorological data (6-hour time step, 1000 and $850 \mathrm{hPa}$ pressure levels) obtained through the Netherlands Meteorological Institute (KNMI) from the European Centre for Medium Range Weather Forecasts (ECMWF) in Reading, England. The basic resolution of these data is $1^{\circ}$ longitude $\mathrm{x}$ $0.5^{\circ}$ latitude. Small scale processes such as dispersion, dry and wet deposition are described on the basis of surface observations of wind speed, cloud cover, temperature, humidity and precipitation. These surface observation data are obtained (mainly as 6-hourly values) from databases kept by ECMWF, the American National Centre for Atmospheric Research (NCAR) and Deutscher Wetterdienst (DWD). The spatial resolution of these small scale processes is limited by the (local) density of the meteorological stations.

Chemical reaction rates are independent of concentration levels, which means that only linear chemistry can be described. The model can be applied with a variable spatial resolution, using a fixed receptor grid or using a set of individual receptor points. In this case, each receptor point is characterised by its co-ordinates, land use class and roughness length. Some extensions were made to the original Eutrend model. The most important one is the introduction of local land use and surface roughness effects on dry deposition. These parameters now can be specified either in grid-form or as properties of the receptors.

\section{CHANGING EMISSION/DEPOSITION PATTERNS DUE TO AFFORESTATION}

The effects of afforestation on emission and deposition patterns can be divided in effects due to land use changes and effects due to growing trees. In Section 3.3 special attention will be paid to spatial interactions between source and receptor, while these spatial interactions are a complicating factor in implementing deposition processes in the AFFOREST-sDSS.

\subsection{Effects due to land use changes}

The land use changes occurring in a afforestation process have two different effects. The first effect is related to the removal of especially $\mathrm{NH}_{3}$ emission, while the second is related to changing deposition characteristics when turning agricultural land into forests. 


\subsubsection{Removal of emission due to afforestation}

When agricultural land is converted to forest a major change in local emissions will be the result. From the moment agricultural practices are terminated $\mathrm{NH}_{3}$ emissions will rapidly decrease and eventually stop. The total mineral $\mathrm{N}$ pool in the soil will determine the period during which emission is still possible after ending the agricultural practices. However, the largest difference in $\mathrm{NH}_{3}$ emission will occur during the first year. The removal of $\mathrm{NH}_{3}$ emission will have an effect on the surrounding areas and therefore introduce spatial interaction into the AFFOREST-sDSS (section 3.3).

\subsubsection{Changing deposition characteristics}

When land use is changed from arable or grassland to forest $\mathrm{N}$ deposition will change. When calculating the dry deposition using the Eutrend model the dry deposition velocity is described by means of a resistance analogy in which:

$$
v_{d}=\left(r_{a}+r_{b}+r_{c}\right)^{-1}
$$

Where:

$r_{a}$ is the aerodynamic resistance,

$r_{b}$ is the boundary layer resistance and

$r_{c}$ is the surface or canopy resistance.

These three resistances represent the three stages of transport from the air to uptake at the surface. The aerodynamic resistance $\left(r_{a}\right)$ represents the resistance against turbulent transport of the component close to the surface (Garland 1978), the quasilaminar sub layer resistance $\left(\mathrm{r}_{\mathrm{b}}\right)$ accounts for the transport of the component by molecular diffusion through a laminar layer adjacent to the surface (Hicks et al. 1987), and the surface resistance $\left(r_{c}\right)$ accounts for the uptake at the surface. Changing from agriculture to forest will have an effect on all these resistances. The changes in $r_{a}$ and $r_{b}$ are mainly related to changing roughness lengths, which will be discussed in the next section.

The effect of changing land use on the canopy resistance $\left(\mathrm{r}_{\mathrm{c}}\right)$ is related to changing uptake processes at the surface. This will have an effect on the deposition velocity, independent of the corresponding roughness length. Calculations showed that the deposition velocity decreases when changing from agricultural land to forest, only taking the effect on $r_{c}$ into account (Table 5.1). For the calculations, specific roughness lengths were used of 0.03 and $0.075 \mathrm{~m}$ for pasture and other arable land, respectively. 


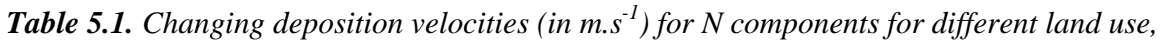

\begin{tabular}{|c|c|c|c|c|}
\hline Component & $\begin{array}{l}\text { Former } \\
\text { land use }\end{array}$ & $\begin{array}{l}\text { Forested land } \\
\text { use }\end{array}$ & dep. vel. $\left(\mathrm{m} . \mathrm{s}^{-1}\right)$ & ratio vd for/vd agr \\
\hline \multirow[t]{6}{*}{$\mathrm{NH}_{3}$} & pasture & & 0.631 & \\
\hline & & coniferous & 0.533 & 0.845 \\
\hline & & deciduous & 0.541 & 0.857 \\
\hline & arable & & 0.760 & \\
\hline & & coniferous & 0.654 & 0.902 \\
\hline & & deciduous & 0.668 & 0.921 \\
\hline \multirow[t]{6}{*}{$\mathrm{NH}_{4}$} & pasture & & 0.059 & \\
\hline & & coniferous & 0.061 & 1.034 \\
\hline & & deciduous & 0.061 & 1.034 \\
\hline & arable & & 0.063 & \\
\hline & & coniferous & 0.065 & 1.032 \\
\hline & & deciduous & 0.065 & 1.032 \\
\hline \multirow[t]{6}{*}{$\mathrm{NO}_{\mathrm{x}}$} & pasture & & 0.129 & \\
\hline & & coniferous & 0.073 & 0.566 \\
\hline & & deciduous & 0.107 & 0.829 \\
\hline & arable & & 0.135 & \\
\hline & & coniferous & 0.076 & 0.563 \\
\hline & & deciduous & 0.112 & 0.830 \\
\hline \multirow[t]{6}{*}{$\mathrm{NO}_{3}$} & pasture & & 0.425 & \\
\hline & & coniferous & 0.425 & 1.000 \\
\hline & & deciduous & 0.425 & 1.000 \\
\hline & arable & & 0.506 & \\
\hline & & coniferous & 0.506 & 1.000 \\
\hline & & deciduous & 0.506 & 1.000 \\
\hline
\end{tabular}

3.2. Changing deposition patterns due to growing trees

After afforestation, the deposition of $\mathrm{N}$ will change due to the effect of growing trees. Growing trees will have an effect on the roughness length, which is an important factor determining the deposition velocity. A change in roughness length will result in a change of mainly $r_{a}$ and $r_{b}$.

In literature, relations between tree height and roughness length are mentioned. A commonly known rule of thumb is

$$
z_{0}=0.1 \cdot h
$$

Where

$\mathrm{h}$ is tree height (in $\mathrm{m}$ )

$z_{0}$ is roughness length (in $\mathrm{m}$ )

Thom (1971) suggested the following relation:

$$
\mathrm{z}_{0}=\lambda \cdot(\mathrm{h}-\mathrm{d})
$$


Where:

$\mathrm{d}$ is the displacement height (appr. $0.7 \mathrm{x} \mathrm{h}$ ) and

$\lambda$ is a parameter ought to be insensitive to vegetation height.

Thom gave a value for $\lambda$ of 0.36 , while Moore (1974) determined a value of 0.26 by analysing 105 published estimates of $\mathrm{d}, \mathrm{z}_{0}$ and $\mathrm{h}$ for several crops ranging from smooth grass to forest. When using 0.26 as a value for $\lambda$, $z_{0}$ will be $1.56 \mathrm{~m}$ at a tree height (h) of $20 \mathrm{~m}$. In general, this approach gives reasonable results.

After establishing a relation between tree height and roughness length, the next step involves the relation between roughness length and deposition velocity. This relationship was established using Eutrend (Figure 5.1). As the trees are growing after afforestation, height and roughness length is increasing and along with this the deposition velocity is increased. The increase in deposition velocity is most important for $\mathrm{NH}_{3}$ than for $\mathrm{NO}_{\mathrm{x}}$.

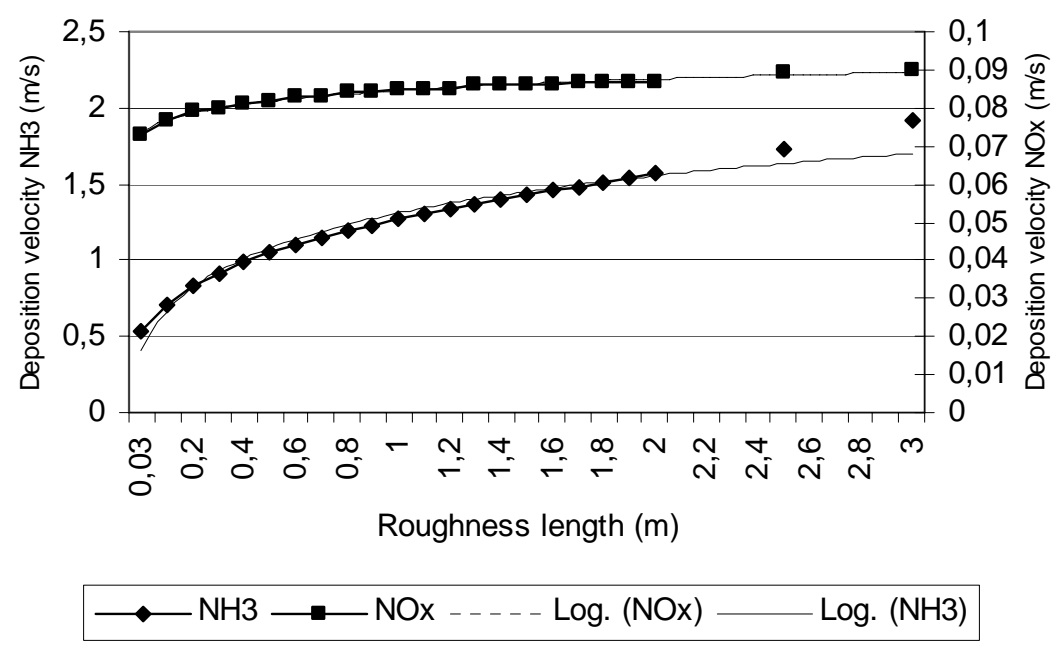

Figure 5.1. Relation between roughness length (m) and deposition velocity $\left(\mathrm{m} . \mathrm{s}^{-1}\right)$ for $\mathrm{NH}_{3}$ and $\mathrm{NO}_{\mathrm{x}}$. The logarithmic trend line is shown for these two relations. Calculated using the Eutrend model.

The respective trend lines for $\mathrm{NH}_{3}, \mathrm{NO}_{\mathrm{x}}$ and $\mathrm{NO}_{3}$ can be represented by the following equations:

$$
\begin{array}{ll}
v_{d}=0.3764 \cdot \ln \left(z_{0}\right)+0.4088 & \text { for } \mathrm{NH}_{3}\left(\mathrm{R}^{2}=0.96\right) \\
v_{d}=0.0046 \cdot \ln \left(z_{0}\right)+0.0736 & \text { for } \mathrm{NO}_{\mathrm{x}}\left(\mathrm{R}^{2}=0.99\right) \\
v_{d}=0.2804 \cdot \ln \left(z_{0}\right)+0.3185 & \text { for } \mathrm{NO}_{\mathrm{x}}\left(\mathrm{R}^{2}=0.97\right)
\end{array}
$$


For $\mathrm{NH}_{4}$ a distinction has to be made for roughness lengths smaller than $0.5 \mathrm{~m}$ and for roughness lengths larger or equal than $0.5 \mathrm{~m}$, due to the underlying processes included in the dry deposition module of the Eutrend model (Ruijgrok et al. 1994). For these two types the corresponding equations are:

$$
\begin{array}{ll}
v_{d}=0.0087 \cdot \ln \left(z_{0}\right)+0.061 & \text { for } \mathrm{NH}_{4} \text { where } \mathrm{z} 0<0.5 \mathrm{~m}\left(\mathrm{R}^{2}=0.99\right) \\
v_{d}=0.0216 \cdot\left(\mathrm{z}_{0}\right)+0.1803 & \text { for } \mathrm{NH}_{4} \text { where } \mathrm{z} 0 \geq 0.5 \mathrm{~m}\left(\mathrm{R}^{2}=0.99\right)
\end{array}
$$

\subsection{Spatial interaction between source and receptor}

Emission from a specific location can be deposited at that same location but is can also be transported through the air and deposited to surrounding areas. A spatial interaction between the emission source and the deposition receptor is introduced through this transport as a complicating factor in the modelling of $\mathrm{N}$ deposition. Spatial interaction will influence the grid based procedures within the AFFORESTsDSS and further investigation was needed to evaluate the relevancy of spatial interaction for the AFFOREST-sDDS. While the AFFOREST-sDSS is considering a change from agricultural land to forest, the focus will be mainly on changing $\mathrm{NH}_{3}$ emissions.

The OPS model was used to determine the spatial relationships in the $\mathrm{N}$ deposition calculations. Calculations were performed for $\mathrm{NH}_{3}$ in meteorological regions in the Netherlands. For a hypothetical area of 25 x $25 \mathrm{~km}$, both dry and wet deposition, of $\mathrm{NH}_{3}$ was calculated for grid cells with a size of $5 \times 5 \mathrm{~km}$. The emission of $\mathrm{NH}_{3}$ originates from a source in the central grid cell and amounts to $0.5 \mathrm{~g} \mathrm{~s}^{-1}$ (i.e. approximately $15750 \mathrm{~kg} \mathrm{yr}^{-1}$ ) for the total grid cell area.

Information is needed on the specific land use characteristics of the considered area in order to calculate the deposition. The calculations were performed for grassland with a roughness length of $0.05 \mathrm{~m}$. In general, the total percentage of $\mathrm{NH}_{3}$ being deposited within the study area of $25 \times 25 \mathrm{~km}$ was on average $20 \%$ of the emitted $\mathrm{NH}_{3}$. Consequently, $80 \%$ of the emitted ammonia was deposited outside the area and thus will contribute to the deposition of ammonia in areas at larger distances from the source.

A distinction was made between dry, wet and total $\mathrm{NH}_{3}$ deposition. About $90 \%$ of the deposited $\mathrm{NH}_{3}$ will be due to dry deposition. This high contribution of dry deposition in the total deposition of ammonia will especially occur on short distances from the source. At larger distances the contribution of wet deposition will increase (Figure 5.2). The total deposition is dominated by dry deposition up to a distance of about $10 \mathrm{~km}$. At larger distances the contribution of wet deposition is gradually increasing. 


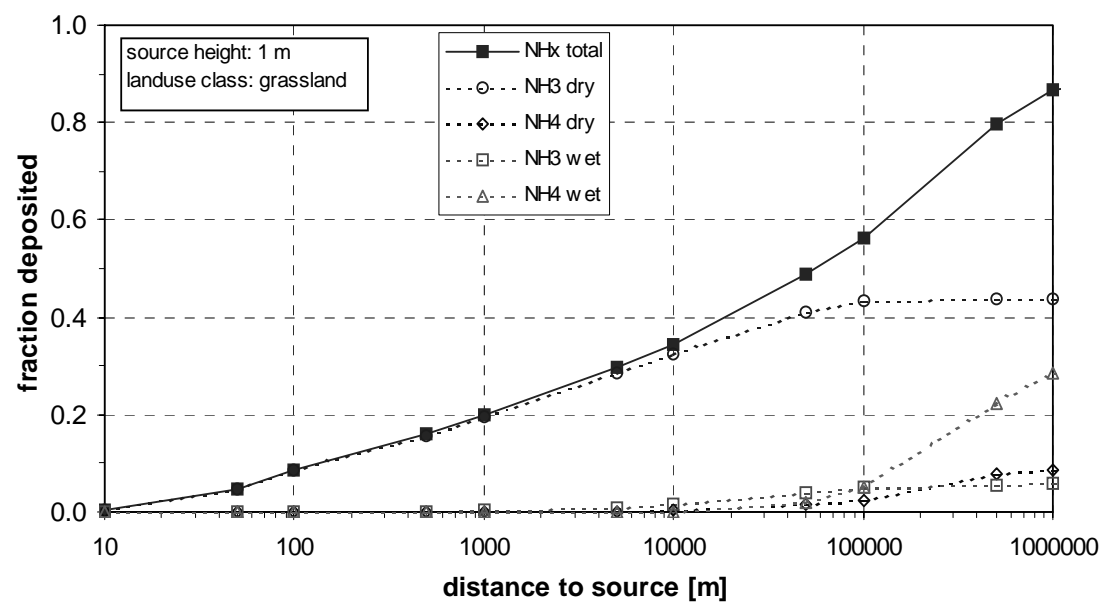

Figure 5.2. Cumulative deposition of $N$ compounds as a function of the downwind distance from a point source calculated using the OPS model.

At a distance of $100 \mathrm{~km}$ from the source, approximately $60 \%$ of the emitted $\mathrm{NH}_{3}$ was deposited, while at distances of about $1000 \mathrm{~km}, 10 \%$ of the emitted $\mathrm{NH}_{3}$ is still not deposited. The contribution of emitted $\mathrm{NH}_{3}$ to the deposition was largest in the emitting grid cell and it decreased quickly to less than $1 \%$ in the surrounding grid cells, however, neglecting these contributions would lead to a significant underestimation of the overall $\mathrm{N}$ deposition. This will especially be the case in areas with high $\mathrm{NH}_{3}$ emissions. The effect of the spatial interactions on the deposition of $\mathrm{NH}_{3}$ is shown in Table 5.2 for the nine grid cells in the centre of the area.

Table 5.2. Calculated deposition of $\mathrm{NH}_{3}$ (in $\mathrm{kg} \mathrm{yr}^{-1}$ ) in the nine central grid cells when excluding (left) and including (right) spatial interactions.

\begin{tabular}{|c|c|c|c|c|c|}
\hline \multicolumn{3}{|c|}{$\begin{array}{c}\text { Spatial interaction } \\
\text { excluded }\end{array}$} & \multicolumn{3}{|c|}{$\begin{array}{c}\text { Spatial interaction in- } \\
\text { cluded }\end{array}$} \\
\hline 2221 & 2221 & 2221 & 2426 & 2595 & 2592 \\
\hline 2221 & 2221 & 2221 & 2495 & 2781 & 2826 \\
\hline 2221 & 2221 & 2221 & 2415 & 2715 & 2805 \\
\hline
\end{tabular}


The influence of spatial interaction on the deposition per individual grid cell varied considerably (Table 5.2), which is mainly determined by the location of a grid cell in reference to the prevailing wind direction. On a small scale of 15 x $15 \mathrm{~km}$, the inclusion of spatial interaction in the calculation will lead to an $\mathrm{NH}_{3}$ deposition, which is $18 \%$ higher compared to neglecting this interaction. In high emission areas, this will especially lead to a large underestimation of the overall $\mathrm{NH}_{3}$ deposition.

Although the effect of spatial interaction on the deposition was only tested for $\mathrm{NH}_{3}$, its effect is estimated to be even higher for the deposition of $\mathrm{NO}_{\mathrm{x}}$, since these oxidised compounds are transported over larger distances.

\section{NITROGEN DEPOSITION IN THE AFFOREST-SDSS}

Based on the information from the previous sections, a methodology was developed by which the effect of afforestation on $\mathrm{N}$ deposition can be simulated in the context of the AFFOREST-sDSS. Calculations made were compared with measurements and the uncertainties described.

\subsection{Methodology of deposition calculation}

The overall methodology for calculating the $\mathrm{N}$ deposition consists of the steps shown in Figure 5.3. These different steps will be further elaborated in this section.

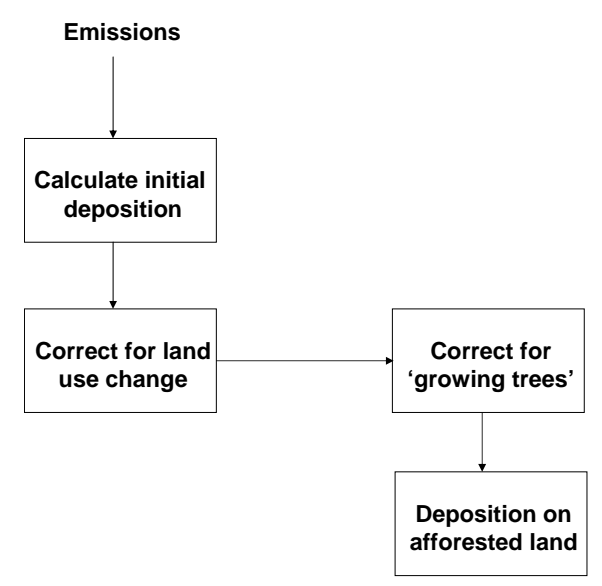

Figure 5.3. The different steps in the procedure for calculating $N$ deposition after afforestation.

\subsubsection{Emissions}

As input to the deposition calculation procedure emissions for both $\mathrm{NH}_{3}$ and $\mathrm{NO}_{\mathrm{x}}$ were used. For the Belgian region Flanders, the Netherlands and Denmark, emissions from national emission databases were available at different resolutions. These 
emissions were redistributed over a $1 \mathrm{x} 1 \mathrm{~km}$ grid over the respective regions on the basis of land use information. $\mathrm{NH}_{3}$ emissions were assigned to agricultural land, while $\mathrm{NO}_{\mathrm{x}}$ emissions were assigned to urban areas and roads. For Sweden, no specific emission data were available. Therefore, emission data from the EMEP emission database were used at a resolution of 50x50 $\mathrm{km}$. These emission data were redistributed over $1 \times 1 \mathrm{~km}$ grid cells using specific land use information. Besides emission data for the individual countries within the AFFOREST region also emission data for surrounding countries outside this region were required. Available emission data for $\mathrm{NH}_{3}$ and $\mathrm{NO}_{\mathrm{x}}$ from the EMEP database were used at a resolution of $50 \times 50 \mathrm{~km}$.

\subsubsection{Calculating initial deposition}

The initial deposition of $\mathrm{N}$ on the AFFOREST region was calculated by means of the Eutrend model and the above mentioned emission data. Information on land use and roughness length are other important input to the model. Specific roughness length and land use maps were constructed on a $1 \mathrm{x} 1 \mathrm{~km}$ resolution. The maps were based on Corine land use information with a 250x250 m resolution (Flanders, the Netherlands and Denmark) and on Swedish land use information with a resolution of $1 \mathrm{x} 1 \mathrm{~km}$. When constructing the new land use database, the original Corine land use classes were reclassified. This was done by using ArcView. The result of this reclassification is shown in Color plate 1 for the AFFOREST region (excl. Sweden).

After reclassification of the initial land use data, the 250x250 m resolution data were aggregated to $1 \times 1 \mathrm{~km}$ based on dominant land use by means of ArcView (Color plate 2). Based on the 250x250 m land use map a roughness map was constructed. For each of the individual land use classes, a specific roughness length was used (Table 5.3) (Color plate 3).

Table 5.3. Land use types used in the Eutrend calculations along with assigned values for roughness length.

\begin{tabular}{ll}
\hline Land use type & Roughness length $(\mathrm{m})$ \\
\hline Pasture & 0.03 \\
Arable land & 0.15 \\
Forest & 1.8 \\
Water & 0.0002 \\
Urban areas & 2.0 \\
\hline
\end{tabular}



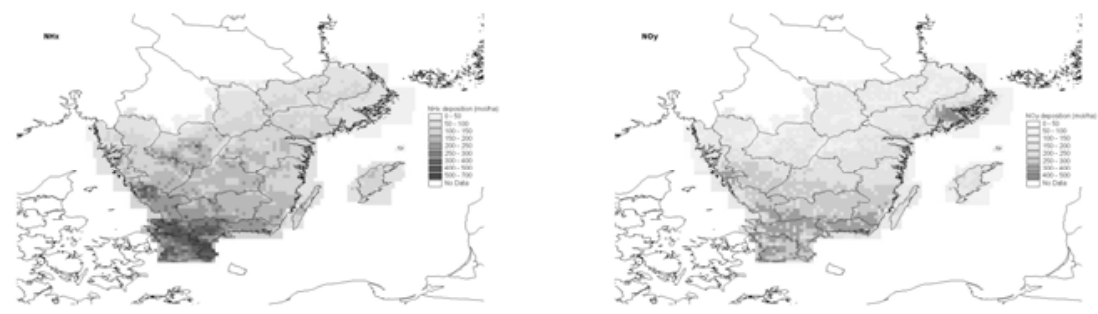

netx
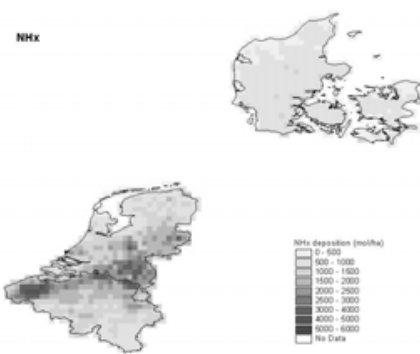

noy
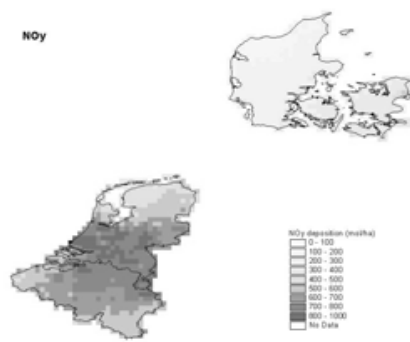

Figure 5.4. Calculated deposition for $\mathrm{NH}_{x}$ (left) and $\mathrm{NO}_{y}$ (right) for the AFFOREST region. The results for Belgium and the Netherlands, Denmark and Sweden are shown separately to get a better overview. Note that Sweden has a different legend than the other areas.

Using emission data, land use data and roughness length maps as an input, the Eutrend calculations were performed. The overall results of these calculations for $\mathrm{NH}_{\mathrm{x}}$ and $\mathrm{NO}_{\mathrm{y}}$ are shown in Figure 5.4. Apparently, the deposition was much higher for Belgium and the Netherlands than for Denmark and Sweden.

\subsubsection{Correction for land use change}

As described earlier, the correction for land use changes consisted of two different corrections. One correction was due to removal of emissions and the other correction was due to changing deposition characteristics because of growing forest. Therefore, the initial deposition already calculated had to be corrected for the halt in emission after change in land use. A specific correction field was calculated showing how one unit of emission was distributed over the surrounding area. The deposition of $\mathrm{NH}_{\mathrm{x}}$ as a percentage of emitted $\mathrm{NH}_{3}\left(1000 \mathrm{~kg} \mathrm{NH}_{3} \mathrm{yr}^{-1}\right)$ in the grid cell from which the emission originates received about $9 \%$ of the emitted ammonia in the form of $\mathrm{NH}_{\mathrm{x}}$ deposition (Figure 5.5). 


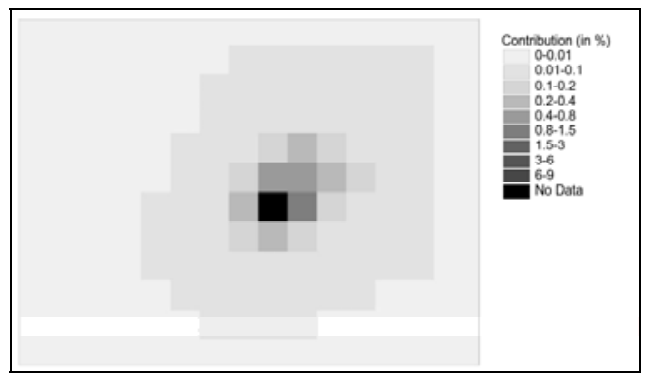

Figure 5.5. Distribution of the emitted $\mathrm{NH}_{3}$ to its surroundings. Deposition of $\mathrm{NH}_{x}$ as a percentage of the emitted $\mathrm{NH}_{3}$.

Including spatial interaction in the AFFOREST-sDSS was rather complicated because of the predefined database structure behind the sDSS. Therefore, a simplification of this spatial interaction was investigated for implementation in the AFFOREST-sDSS. It was assumed that three situations can be distinguished. These are i) removing emission only affects the emitting grid cell (no interaction), ii) removing emission has an effect on all the surrounding grid cells (complete spatial interaction) and iii) removing emission has an effect on e.g. surrounding grid cells within $5 \mathrm{~km}$ (limited spatial interaction).

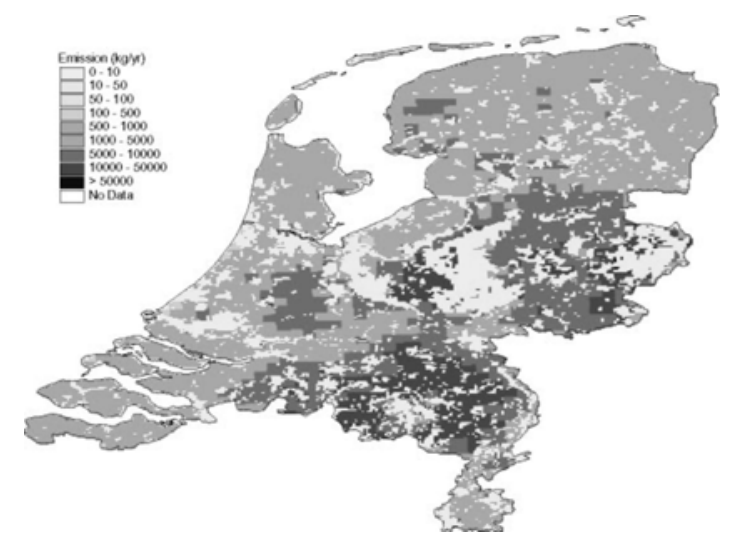

Figure 5.6. Emission of $\mathrm{NH}_{3}$ in the Netherlands.

When individual cells are considered in the AFFOREST scenarios spatial interaction does not have to be taken into account. Only the contribution of the emission to that specific grid cell has to be considered. However, when grid cells in the surrounding of that specific emitting cell were also evaluated, spatial interaction played a role. On beforehand, it was not clear which situation would occur. It all depends on the question the end user of the AFFOREST-sDSS wants to have answered by the system. The different aspects involved in this correction procedure are show in 
Figures 5.6 to 5.9, taking the Netherlands as an example. The first map shows the emission of $\mathrm{NH}_{3}$, while the two following maps show the minimum (no interaction) and the maximum (complete spatial interaction) correction procedure. Figure 5.8 shows the initial total $\mathrm{N}$ deposition, while

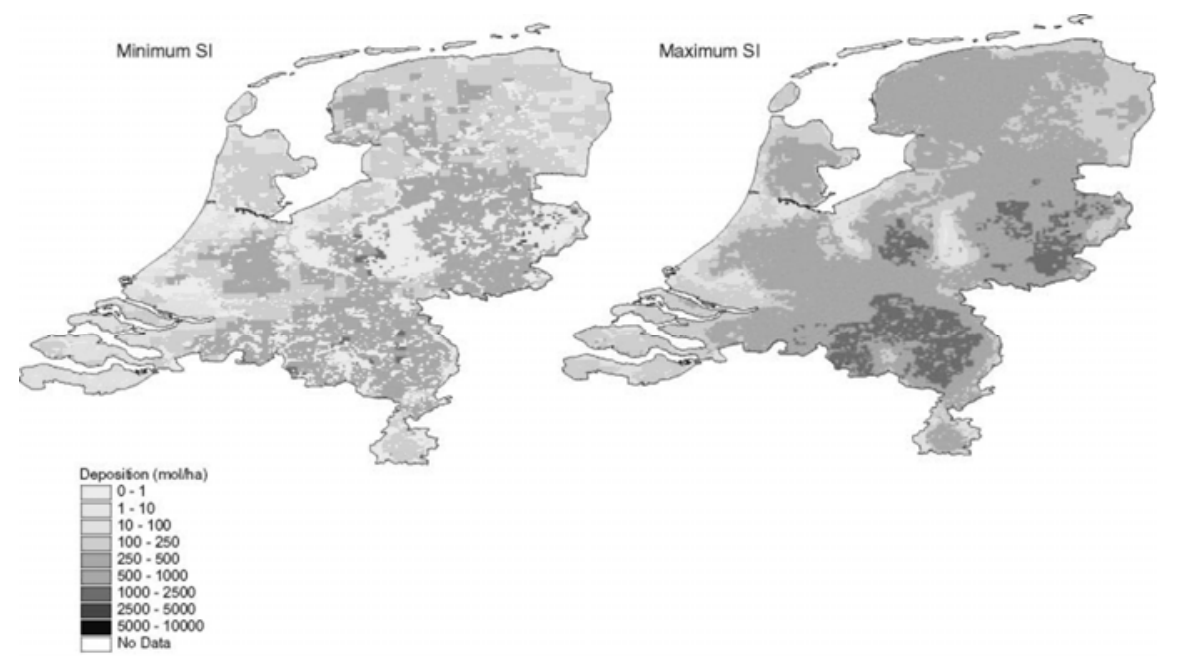

Figure 5.7. Deposition to individual grid cells according to the minimum (no interaction) and the maximum (complete spatial interaction) scenario.

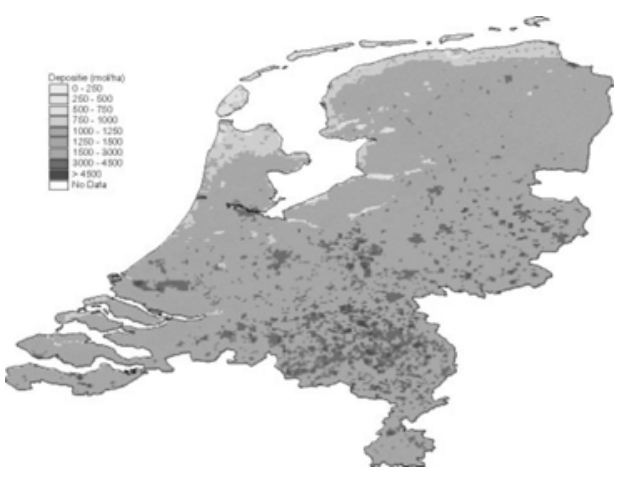

Figure 5.8. Initial total $N$ deposition in the Netherlands.

Figure 5.9 shows two maps with the corrected $\mathrm{N}$ deposition according to the minimum and maximum scenario. Since it is not possible to know on forehand which scenario to choose for answering specific questions, it was decided to average the minimum and maximum scenarios as an estimate for the deposition situation after afforestation. For the different countries within the AFFOREST region these corrections were performed, both according to the minimum and the maximum sce- 
nario. The information on the initial deposition, together with the minimum and maximum corrected deposition is inserted in the AFFOREST-sDSS database for use in the metamodel METAFORE.
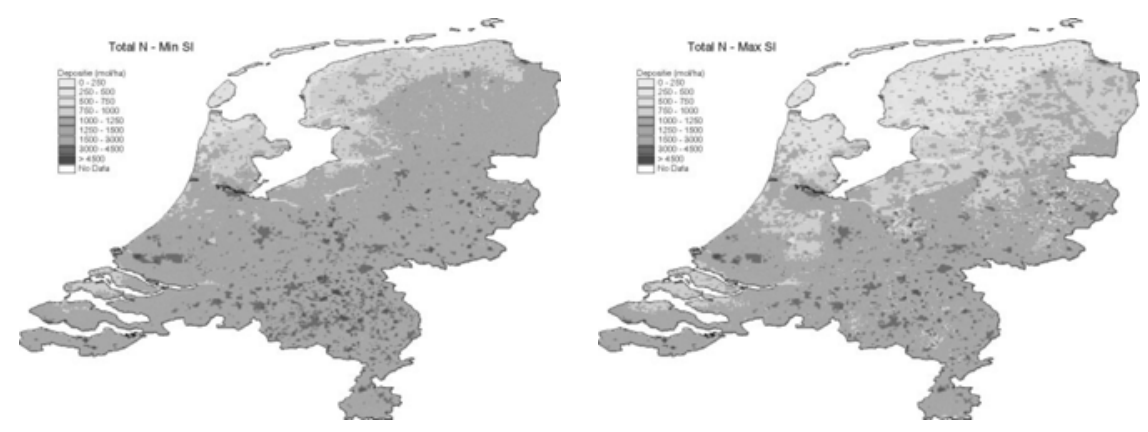

Figure 5.9. Corrected initial $N$ deposition in the Netherlands according to the minimum (left) and maximum (right) scenarios.

\subsubsection{Correction for growing forest and changing deposition characteristics}

For the correction of the initial deposition due to the growing forest and changes in deposition characteristics, four different situations can be distinguished. These situations depend on the initial land use (pasture or arable) and the tree species used for afforestation (coniferous or deciduous). The overall correction equation used in this procedure is:

$$
N_{t d, c o r}=N_{d d, i n i} \cdot \operatorname{corr}_{r c} \cdot \operatorname{corr}_{z 0}+N_{w d, i n i}
$$

where:

$N_{t d, c o r} \quad$ corrected total $\mathrm{N}$ deposition

$N_{d d, \text { ini }} \quad$ initial dry $\mathrm{N}$ deposition

$N_{\text {wd,ini }} \quad$ initial wet $\mathrm{N}$ deposition

corr $_{r c}$ correction of the initial deposition due to changing land use

$\mathrm{corr}_{z 0}$ correction of the initial deposition due to growing forest

The general assumption is that the total $\mathrm{N}$ deposition is formed by $60 \%$ dry and $40 \%$ wet deposition and that only the dry deposition part changes due to changing land use and growing forest. Therefore:

$$
N_{t d, \text { cor }}=N_{t d, i n i} \cdot 0.6 \cdot \operatorname{corr}_{r c} \cdot \operatorname{corr}_{z 0}+N_{t d, i n i} \cdot 0.4
$$

For the four situations different correction factors can be distinguished (Table 5.4) 
Table 5.4. Correction factors for different initial situations (pasture or arable land) when planting either deciduous or coniferous tree species.h is the tree height in $\mathrm{m}$.

\begin{tabular}{|l|l|l|}
\hline Before-after situation & & \\
\hline pasture - coniferous & $\operatorname{corr}_{r c}=0.907$ & $\operatorname{corr}_{z 0}=(0.6789 \ln (h)+0.8689)$ \\
\hline pasture - deciduous & $\operatorname{corr}_{r c}=0.9142$ & $\operatorname{corr}_{z 0}=(0.6789 \ln (h)+0.8689)$ \\
\hline arable - coniferous & $\operatorname{corr}_{r c}=0.9412$ & $\operatorname{corr}_{z 0}=(0.5297 \ln (h)+0.678)$ \\
\hline arable - deciduous & $\operatorname{corr}_{r c}=0.9526$ & $\operatorname{corr}_{z 0}=(0.5297 \ln (h)+0.678)$ \\
& & \\
\hline
\end{tabular}

These correction factors are an average for the dry deposition of $\mathrm{NH}_{\mathrm{x}}$ and $\mathrm{NO}_{\mathrm{y}}$. In general, the distribution over for $\mathrm{NH}_{\mathrm{x}}$ and $\mathrm{NO}_{\mathrm{y}}$ is $60 \% / 40 \%$ for agricultural areas. For very intensive agricultural areas this distribution can change to $80 \% / 20 \%$, while in extensive agricultural areas in the neighbourhood of urban areas this might be $40 \% / 60 \%$. However, these differences will have relatively little effect on the average correction factors. Figure 5.10. shows the result for the total correction of the initial deposition as a function of tree height for the situation where pasture is converted to coniferous trees.

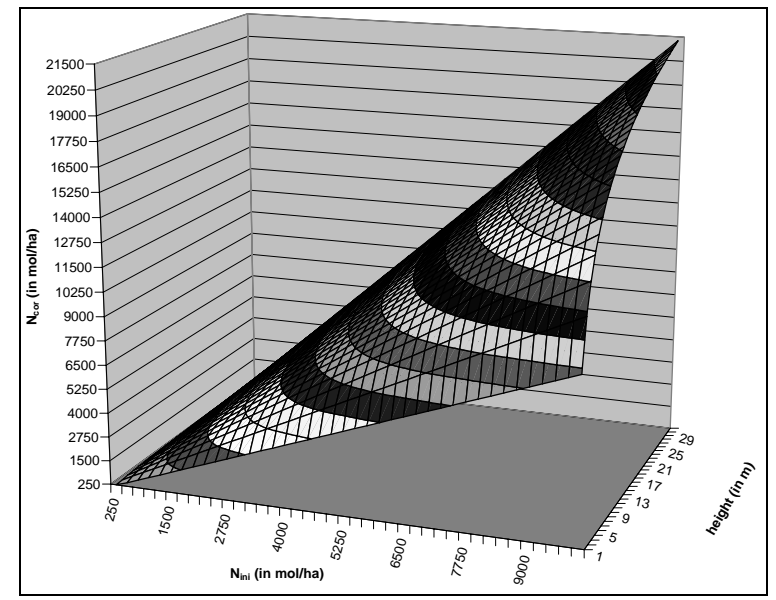

Figure 5.10. Example of the effect the correction procedure has on the initial deposition as a function of tree height when pasture is changed to coniferous forest. 


\subsubsection{Deposition to afforested land}

The total procedure for calculating the deposition on afforested land can now be performed (Figure 5.3). The initial deposition was calculated for the individual AFFOREST region countries, based on country specific emissions. When certain grid cells are to be afforested, the existing deposition is corrected according to the procedure described. Hereafter, the remaining deposition is corrected due to the effect of enhanced deposition because of growing forest. The resulting deposition after these two corrections is used within the AFFOREST-sDSS to describe the deposition situation after a certain amount of years after afforestation.

\subsection{Comparison with measurements and other calculation results}

The calculated $\mathrm{N}$ deposition was compared with measured deposition on the AFFOREST chronosequence sites in Sweden, Denmark and the Netherlands. The experimental data were mapped on top of the modelled total $\mathrm{N}$ deposition. The data were modelled using both the Eutrend model and the EMEP model, which is used in overall European deposition studies. The comparison between measured and modelled bulk $\mathrm{N}$ deposition is shown in Table 5.5 .

Table 5.5. Comparison between measured and modelled $N$ deposition $\left(\mathrm{kg} \mathrm{ha}^{-1}\right)$

\begin{tabular}{lccc}
\hline Location & \multicolumn{3}{c}{ N-deposition $\left(\mathrm{kg} \mathrm{N} \mathrm{ha}^{-1}\right)$} \\
\hline Sweden (spruce) & Measured & Eutrend & EMEP \\
the Netherlands (oak) & $18 \pm 4$ & 6 & 12 \\
the Netherlands (spruce) & $16 \pm 2$ & 16 & 22 \\
Denmark 1 (spruce) & $28 \pm 7$ & 21 & 22 \\
Denmark 2 (oak) & $15 \pm 0.3$ & 10 & 15 \\
\hline
\end{tabular}

The comparison showed fairly good results, except for Sweden, which was out of range. The Dutch spruce site was underestimated but the three bulk samplers had a high site specific variability, which could explain part of the differences. The EMEP and the Eutrend models were run for only one year of meteorological data, which in reality will vary between years as well. Both measurements and calculations are subject to uncertainties that can not always be quantified. The overall comparison is influenced in a qualitative way by different sources of uncertainty:

- Field measurements are only performed during one or two years and it is not always clear if these measurements represent the average situation

- measurements are monthly and missing values due to different reasons will have a large influence on the total deposition

- deposition models have an inherent uncertainty in the way processes are modelled and in parameters used as well as input required

- emissions used have large uncertainties, especially at high resolutions. 
- $\mathrm{NH}_{3}$ emissions show a high spatial and temporal variation, which will be the cause of large uncertainties when the deposition is evaluated at specific locations

- use of different emission databases (as mentioned in previous sections) will cause additional uncertainties, because of difference in calculation approaches, input data, resolution differences, etc.

- differences in meteorological conditions from year to year can cause deposition difference of up to $30 \%$

These topics can add up to large uncertainties. However, within the overall AFFOREST-sDSS these uncertainties have to be judged in the context of the other components of the system. Emphasis should be more on the overall trend and plausibility of the modelling results than on the absolute results for individual locations (Chapter 10).

\section{DISCUSSION AND CONCLUSIONS}

Since $\mathrm{N}$ deposition is one of the most environmentally damaging air pollutants in north-western Europe, atmospheric $\mathrm{N}$ is considered an important input to the AFFOREST system. The Eutrend model is used for the AFFOREST calculations Emission, dispersion, advection, chemical conversion and wet and dry deposition are included in the model.

Because of the transport of $\mathrm{N}$ through the air a spatial interaction between the emission source and the deposition receptor is introduced since $\mathrm{N}$ emissions from a specific location is transported and deposited in surrounding areas. We investigated The relevance of spatial interaction between grid cells for the AFFOREST-sDDS was investigated.

The calculated $\mathrm{N}$ deposition was compared with measured deposition on the AFFOREST chronosequence sites in Sweden, Denmark and the Netherlands. The comparison showed fairly good results (except for Sweden) but both measurements and calculations are subject to uncertainties that are not easily quantified.

For European scale afforestation projects there is a need for detailed information on the effect of the receiving surface on the amount of atmospheric deposition. Deposition models have an inherent uncertainty in the way processes are modelled and in parameters used as well as input required. Despite the uncertainties, the developed methodology provides a good means for producing this kind of information on a 250 x $250 \mathrm{~m}$ scale. This deposition modelling approach, as part of the scientific development process in the AFFOREST project, has been fairly comprehensively validated and calibrated. We conclude that the results are satisfactory to include in the METAFORE metamodel (Chapter 9). 


\section{REFERENCES}

Asman, W. A. H., \& Van Jaarsveld, J. A. (1990). A variable-resolution statistical transport model applied for ammonia and ammonium. RIVM Report no. 228471007, National Institute of Public Health and Environment, Bilthoven, The Netherlands

Asman, W. A. H., \& Van Jaarsveld, J. A. (1992). A variable-resolution transport model applied for $\mathrm{NH}_{\mathrm{x}}$ for Europe. Atmospheric Environment, 26A, 445-464.

Bleeker, A., Draaijers, G. P. J., Klap, J., \& Van Jaarsveld, J. A. (2000). Deposition of acidifying components and base cations in Germany in the period 1987-1995. RIVM Report no. 722108027, National Institute of Public Health and Environment, Bilthoven, The Netherlands.

Chamberlain, A.C. (1966). Transport of gases to and from grass and grass-like surfaces. Proceedings of the Royal Society Service, A290, 236-265.

Erisman, J. W., Van Pul, A., \& Wyers, P. (1994). Parameterization of dry deposition mechanisms for the quantification of atmospheric input to ecosystems. Atmospheric Environment, 28, 2595-2607.

Fowler, D. (1978). Dry deposition of $\mathrm{SO}_{2}$ on agricultural crops. Atmospheric Environment, 12, 369-373.

Fowler, D., Duyzer, J. H., \& Baldocchi, D. D. (1991). Inputs of trace gases, particles and cloud droplets to terrestrial surfaces. Proceedings Royal Society Edinburgh, 97B, 35-59.

Garland, J. A. (1978). Dry and wet removal of sulfur from the atmosphere. Atmospheric Environment, 12, 349.

Hicks, B. B., Baldocchi, D. D., Meyers, T. P., Hosker Jr., R. P., \& Matt, D. R. (1987). A preliminary multiple resistance routine for deriving dry deposition velocities from measured quantities. Water Air Soil Pollution, 36, 311-330.

Hicks, B. B., Matt, D. R., \& McMillan, R. T. (1989). A micrometeorological investigation of surface exchange of O3, SO2 and NO2: a case study. Boundary-Layer Meteorology, 47, 321-336.

Hov, O., Allegrini, I., Beilke, S., Cox, R. A., Eliassen, A., Elshout, A. J., Gravenhorst, G., Penkett, S. A., \& Stern, R. (1987). Evaluation of atmospheric processes leading to acid deposition in Europe. Report 10, EUR 11441, CEC, Brussels.

Millennium Ecosystem Assessment, 2005. Ecosystems and Human Well-being: Biodiversity Synthesis. World Resources Institute, Washington, DC.

Thom, A.S. (1975). Momentum, mass and heat exchange of plant communities. In: J.L. Monteith (editor), Vegetation and Atmosphere. London: Academic Press, pp. 58-109.

Van Jaarsveld, J. A. (1995). Modelling the long-term atmospheric behaviour of pollutants on various spatial scales. Ph.D Thesis, University of Utrecht, The Netherlands. 